\title{
IAMJ
}

INTERNATIONAL AYURVEDIC MEDICAL JOURNAL

\section{A REVIEW OF HEALTH BEHAVIOUR DYNAMICS IN AYURVEDA}

\author{
$\underline{\text { Dileep. G. L }}{ }^{1}, \underline{\text { Jishnu. }^{2}},{\underline{\text { Athri. S. } S^{3}}}^{3}$
}

${ }^{1}$ PG scholar, ${ }^{2,3}$ Associate Professor

Pankajakasturi Ayurveda Medical College and PG Centre, Kattakada, Thiruvananthapuram, India

\section{Corresponding Author:dileep90g|@gmail.com}

https://doi.org/10.46607/iamj3709082021

(Published Online: August 2021)

Open Access

(C) International Ayurvedic Medical Journal, India 2021

Article Received:24/07//2021 - Peer Reviewed:02/08/2021 - Accepted for Publication:03/08/2021

\section{Check for updates}

\begin{abstract}
Health behaviour was essentially a part of sociology. It has now evolved as an individual branch focusing on human therapeutic care. The human behaviour or actions that have a definite impact on his health is named health behaviour. Those which complements one's health are known as positive health behaviours. The negative/altered health behaviour is considered one of the major causative factors for diseases. Alterations from the ideal health behaviour (misdeeds) are due to the wrong psychotic process. These unhealthy behaviours are usually focused on few factors like food, physical activities, sleep, sex and substance use. The positive, as well as negative impacts of behaviour on health, should be understood as part of sociology about psychology, medicine and ethics. In ancient literature, there were such descriptions of health behaviour in the form of do's and don'ts or taboos. Ayurveda considers misdeeds (prajnaparadha) as the root cause of diseases. They are happening by an unsuitable psychotic process like ignorance (unawareness), lack of control/thinking over actions or lack of remembrance. This work attempts to list out the health behaviours mentioned in Ayurveda. The ways to abstain from such misdeeds are also disclosed here.
\end{abstract}

Keywords: health behaviour, Prajnaparadha 


\section{INTRODUCTION}

All living beings are supposed to engage in certain actions and abstain from few others for healthy existence. Human beings being the most advanced species exercise good caution while performing any known activities. From the historical data of any crisis, humans develop precaution and management protocols to tackle future incidences. This behaviour should have developed after observing the healthy as well as ill effects of certain actions/contacts. All these are apparently due to the human thrive to live. Maintaining optimum health by refining one's behaviour was regarded as of prime importance. But the society has witnessed steady changes throughout history. The social norms are different for different cultures, regions or periods. Hence the health behaviour described in any classical literature should be comprehended concerning the place and time (occasion).

Human behaviour -is the potential and expressed capacity for physical, mental, and social activity during the phases of human life ${ }^{1}$. It includes the physical actions, verbal behaviour, facial expressions as well as bodily gestures of an individual. Health behaviours refer to the beliefs of an individual concerning health and well being along with the subsequent intentional and unintentional actions. ${ }^{2}$ This can favour either the health or the ill-health of the doer as well as others interacting with him. Health behaviours influence the quality of life. Usual examples of health behaviours that have a definite negative impact are smoking, substance use, improper diet, physical activity, improper sleep habits, risky sexual activities etc. Hence refraining from unhealthy behaviours is essential to delay the progression of diseases, prevent morbidity and extend the active life span.

Health behaviours are influenced by the social, cultural, and physical environments in which one lives. They are shaped by individual choices and external constraints. Health behaviours are habitually discussed as individual-level behaviours, but they can be measured and summarized for individuals, groups, or populations. Health behaviours are dynamic i.e. it varies over one's lifespan, across cohorts, across settings and over time.
Human behaviour is a dynamic phenomenon that changes due to factors such as new experiences, learning, socio-cultural variations, biological and psychological processes. The genetic makeup, sex differences, physical growth, nutrition, illness, and inborn disabilities are grouped under biological/physiological dynamics of human behaviour. Psychological dynamics of human behaviour are cognition, perception, emotions, attitudes, memory, psychological needs and psychological illness. The socio-cultural dynamics include socio-economic status, education, impacts of technological development, urbanization, social preferences towards dresses and food, gender expectations, traditions and customs ${ }^{3}$. These all highlight the evolutionary nature of human behaviour.

The relationship between an individual's behaviour and his health status has received immense recognition in recent times. However, in ancient Indian literature, we can find this concept is explained in its scientific way. The classics of Ayurveda enlist such health behaviours having an impact on one's health, familial health as well as societal health. These health behaviours can be studied only if we consider them along with the socio-cultural standards of those times. Even though the settings remain continuously changing, the principles behind them remain the same. So, it will not be in vain if we pick up the principles and validate the rules for present living. This study intends to collect those health behaviours as mentioned in the classics of Ayurveda that has been analyzed and discussed considering the current socio-cultural settings.

\section{OBJECTIVES}

To learn the health behaviour dynamics in Ayurveda

\section{MATERIALS AND METHODS}

The material for the study was collected from various modern textbooks and textbooks of Ayurveda. A comparison of the narrations on health behaviour in the modern texts and the classical works of Ayurveda was done. 


\section{RESULTS}

Health behaviour can be considered as the outcome of the beliefs and corresponding actions of individuals. It is a product of intellect, determination/willpower, and remembrance. The actions were done without proper knowledge, positive attitudes, virtues and analyzing previous experiences lead to ill health. For avoiding this, a list of positive health behaviours is enlisted in the classics under the daily routines, seasonal regimens, dietary rules as well as rules and regulations related to sleep, sex, exercise etc. Here we can find that the narrations even refer to the social and moral behaviours along with physical and mental aspects. Thus, it can be generally stated as 'unhealthy behaviour' is simply disobeying the routines and rules enlisted in the textbook. ${ }^{4}$

Health behaviours in modern books and classics of Ayurveda

\section{Modern Aspect}

A balanced diet, regular exercise, adequate sleep, risky sexual activities, smoking, substance abuse, physical inactivity, risky drinking and risky driving are emphasised in modern books. The health behaviours concerned with the body, emotion, social and moral aspects are handled by separate professionals despite being the limbs of human psychology. Also, the determinants of behaviour related to each aspect are of considerable significance to concerned fields.

\section{Ayurveda Aspect}

The instructions for preserving individual health and social wellbeing are well-referred to in the 'Indriyaupakramaneeya' chapter of Charaka Samhita. The chapter provides a more comprehensive insight on the subject when compared to modern discussions. This is because Ayurveda considers the subject as a whole topic by assembling the physical, psychological, social and moral health behaviours in the same chapter. The health behaviours detailed in the context are enlisted below.

\section{Hygiene}

- Should bath twice a day

- Maintain cleanliness of excretory passages and feet
- Maintain a regular hair pattern by Cutting off hair and shaving regularly (once in five days). Maintain an acceptable hairstyle according to one's profession.

- Nails should be clipped regularly

- Always wear untorn clothes, be cheerful and use flowers \& fragrance. Overall attire should be gentle

- One should apply oil to the head, ear, nose, and feet daily

\section{Verbal hygiene}

- One should take an initiative during discourses and remain pleasant face.

- One should speak timely, useful, measured, sweet and with meaningful words

- One should not tell lies

\section{Mental hygiene}

- Should be self-controlled \& virtuous

- One should be free from anxiety, fearless, shy (from committing bad deeds), wise, highly enthusiastic, skilful, fore bearing, religious, with a positive attitude

- One should adopt an auspicious conduct

\section{Respect the respectful,}

- Always respect and follow highly accomplished persons, the elderly and teachers. God, cultured personalities, and preceptors should be kept as models

- One should be devoted to the teachers, accomplished persons and to those who are superior in modesty, intellect, learning, clan and age.

- Respect the yields (like cows), wealth and food (things needed for existence).

- One should not speak ill of noble persons and preceptors.

- One should not perform spells, worship of sacred trees and superiors, and studies while remaining impure. (Be serious in any kind of performance)

- One should not pass the respectable and the auspicious on the left and others on the right side.

- One should not leave home without touching the gems, ghee, the respectable, the auspicious and flowers. 


\section{Perform the traditional rituals}

- One should honour fire with oblation,

- should put on auspicious herbs

- Should offer an oblation, perform religious sacrifices, donations, pay attention to the road crossings, offer Bali (religious offerings or ritualistic sacrifices)

- offer pindas (rice balls) to forefathers

\section{Help others}

- One should save persons in dire situations or distress

\section{Behave as cultured in the society}

- Should not - laugh loudly, release flatus with sound, should not yawn, sneeze, or laugh with the uncovered mouth, should not contort the nose, grind teeth, make scratching sounds using nails, strike the bones, scrape the earth, cut the grass, press the earthen lamp, perform any improper actions of body parts.

- One should not spit out sputum, pass faeces and urine in front of the winds, fire, water, the moon, the sun, cultured people and the preceptors.

- One should not urinate on the road, in crowded (public) places and while taking food.

- One should not let out oral or nasal excreta at the time of recitation of sacred hymens, oblation, studies, and sacrifice, religious and auspicious acts

\section{Codes for social behaviour}

- One should not deviate from generally approved social practices and should not break any code of conduct.

- One should not move in the night or an inappropriate place. One should not indulge in taking food, studies, sexual relations or sleep during the dawn or dusk.

- One should not make friendship with children, the old, the greedy, the fools, the persons under affliction and the eunuchs.

- One should not have an interest in making wine, gambling, and making a physical relationship with prostitutes.
- One should not disclose secrets and should not insult anybody. One should not be self-conceited, unskilled, inexperienced, and envious.

- One should not insult the cultured personalities (brahmins). Please don't beat the cow with sticks. One should not abuse the old, the preceptors, the administrative class, and the king.

- One should not speak too much and irrelevantly

- Treat the kins, persons attached, and persons stood along in difficult times

- Never treat disparagingly the persons who know the secrets.

- One should not be impatient, or overexcited/ over exhilarated.

- One should not be the person who does not support his attendants, confide in his kins, be happy alone and has unpleasant conduct, behaviour, and attendance.

- One should not trust or be doubtful too much towards others.

- One should not insult women and should not place too much faith in them. One should not disclose secrets to them nor should give authority indiscriminately.

- Should offer hospitality to guests,

- One should be zealous to the cause but not be anxious about the result/outcome

\section{Refrain from bad acts}

- Should not take other's possessions

- Should not covet other's women or property

- Should not indulge in enmity, sinful acts, or be cruel (even to a sinner)

- Should not point out defects of others and should not try to know other's secrets

- One should not keep the company of the unvirtuous, those hated by the king, insane persons, those not following social ethics, foetus killers, wretched and wicked ones

- One should not see light, undesirable, impure and inauspicious objects, should not produce any abnormally loud sound at the sight of a corpse and tread on the shadow of sacred persons, teachers, revered ones or any such persons. 
- One should not stay for long in the temples, sacred places, raised platforms, crossroads, gardens, cremation grounds \& places of execution during nights, and should not enter a deserted house or forests alone.

- One should not be attached to women, friends, and servants with sinful conduct, should not oppose or antagonize superior persons and be attached to inferior persons.

- One should not take interest in crooked things, take refuge from wicked persons, and indulge in frightening/ terrorising acts.

- One should not indulge in undue courage. Never approach harmful animals and those having prominent teeth and horns.

- One should not stay for long with knee up

- One should not initiate quarrels.

\section{Moral codes}

- Should behave like a brother to all living beings (i.e., should be compassionate), should pacify the angry and the discontent, and console the frightened

- Should help the poor, be truthful \& peaceful.

- Should be tolerant of harsh words, and should curb the practice of intolerance

- Should always concentrate on the qualities of peaceful life and should be the remover of the causes of attachment and aversion

\section{Preventive health behaviour}

- Follow the Codes/Etiquette for eating

- Should discontinue exercise before the feeling of fatigue.

- Better to avoid night awakening and daytime sleep.

- One should walk with an umbrella, stick, turban $\&$ footwear, and look six feet ahead

- Should avoid places with dirty clothes, bones, thorns, impure particles, hairs, chaff, garbage, ash, and skull

- One should not ride on defective vehicles, sit on a hard place of knee height, sleep on an uncovered hard bed or having no pillow, not having sufficient dimensions or uneven
- One should not move on uneven tops of the mountains, climb trees, and take a dip in the water with strong currents

- One should not tread on the shade of a bank, or move around the places that are prone to fire hazards

- One should not be exposed to easterly winds, the sun, dews and the strong currents of wind.

- One should not sneeze, eat and sleep in a curved position.

- One should not be engaged in other works while urging for the natural urges.

- One should follow the path of brahmacharya (disciplined living/celibacy), knowledge, charity, friendship, compassion, cheerfulness, detachment and peace.

\section{Safe sex behaviour}

- One should not perform sexual intercourse with a woman during her menstrual period, with a woman suffering from a disease, or one who is impure, inauspicious, with undesirable appearance, with bad behaviour/conducts and manners or with the one devoid of skills.

- One should not perform sexual intercourse with women who are not friendly, or one who is not having a passionate desire or has a passionate desire for some other person or is married to some other person.

- One should not perform sexual intercourse with other animal species except human beings, and with other body parts except genitals.

- One should not perform sexual intercourse under holy trees, at sacred places, in the public courtyard, on a crossroad, in a garden, at the cremation ground, execution place/ slaughterhouse, near water reservoir, in the medicine stores. Sexual intercourse is also prohibited in the houses of brahmins, teachers and temples.

- One should not perform sexual intercourse during the dawn and dusk and on inauspicious days i.e. on full moon days and pratipadas (first day of the lunar month), etc. One should not perform sexual intercourse if unclean, if not taken aphrodisiacs, without prior determination and desire, without 
having a proper erection, without food or after excessive food intake, on uneven place, while under the urge of micturition or defecation, after exertion, physical exercise, during fasting, after exhaustion or in a place having no privacy

\section{Codes of Studying}

- One should not study when there is unseasonal lightning, houses appear as if they are burnt, during an outbreak of fire, earthquake, grand festivals, fall of meteors, eclipses (solar or lunar). One should not study on a new moon day, during dawn or dusk.

- One should not study without being instructed by the preceptor. One should not pronounce words in low, high, weak, or deranged voice, without proper accents and morphological symmetry, neither too fast nor too slow, nor with excessive delay and nor with a too high or too low pitch of the sound

\section{Health care seeking}

- Cure the disease immediately

- Take medications from qualified persons

Code of conduct at workplace (employee behaviour)
- One should not be in a habit of postponing things at the time of action.

- One should not indulge in any activity without properly examining it.

- One should not be submissive to his senses nor should let his fickle mind move around.

- One should not overburden his/her intellect or senses.

- One should avoid procrastinating.

- One should not do things in a fit of anger or rejoicing.

- One should not be under continuous grief.

- One should not be conceited over achievements or desperate in the loss.

- One should always remember his constitution of mind (nature).

- One should have faith in the correlation of the cause and effect that is good and bad deeds and their corresponding results and should always act on it.

- $\quad$ One should not be despondent and assume that now nothing can be done.

- $\quad$ One should not lose spirit (give up the courage) nor should remember his insults.

Table1: Showing the popular health behaviours in Modern and Ayurveda

\begin{tabular}{|l|l|}
\hline Modern & Ayurveda \\
\hline Balanced diet & Annapaanavidhi \\
\hline Regular exercise & Vyayama, \\
\hline Adequate sleep & Atinidra, Alpanidra, Divaswapna \\
\hline Risky sexual activities & Over sex indulgence, Maithunavidhi \\
\hline Smoking & \\
\hline Substance abuse & Substance abuse \\
\hline Physical inactivity & Asyasukha \\
\hline Risky drinking & Madatyaya \\
\hline Risky driving & Dushtayana \\
\hline & Suppression/arousing of natural urges (14 urges) \\
\hline & Not giving proper treatment in time \\
\hline & Risky adventures \\
\hline & Untimely trips to the wicked areas \\
\hline & Maintain good codes and conduct \\
\hline & Company with bad people \\
\hline & Habit/activity related with Eershya, Maana, Bhaya, Krodha, Lobha, Moha, Mada, Bhrama \\
\hline
\end{tabular}


The development of health behaviour can be explained in terms of the psychotic processes underlining the behaviour. The common ill-health behaviours are those simple mistakes like the initiation of action without understanding the possible consequences, misunderstanding the idea of consciously avoid evaluating the consequences. These same mistakes can even contribute to serious psychotic illnesses but in varying degrees. This becomes the prime reason for misinterpreting the term prajnaparadha (misdeeds / wrong deeds) as intellectual errors resulting from defects in intellect, understanding and memory. In reality, the simple mistakes one commit randomly in daily life are called misdeeds. When the same happens beyond one's control can present as psychotic illness.

In Ayurveda, the determinants of behaviour and their influences on health are mentioned in various contexts. They are the factors defining the nature of an individual as well as the factors defining growth and development of the body (shareeravriddhikara bha$v a)^{5}$, mind (satwavaisheshikakara bhava $)^{6}$ and power of the individual (balavriddhikara bhava) ${ }^{7}$. They include genetic factors, inherited environmental factors, diet, physical activity, social elements, economic status, region of living (safe area), good environmental conditions, familial background, age, self-attitude and manner. The behavioural dynamics, as well as the health behaviour, is generally interpreted in Ayurveda based on the condition of the human body and influencing the environment (place and time). For example, it has been stated generally that daytime sleep is not good for health. But Acharya instructs the same is beneficial for the old people, children and who are injured. While considering the behavioural dynamics in Ayurveda, the conditional differences need to be understood properly.

Table2: Showing the determinants of health behaviour in Modern and some of the imprints in Ayurveda.

\begin{tabular}{|l|l|}
\hline Modern & Ayurveda \\
\hline $\begin{array}{l}\text { new experiences, learning, socio-cultural variations, } \\
\text { Illness, inborn disabilities }\end{array}$ & $\begin{array}{l}\text { Ritu, kshetra, Ambu \& beeja; Some descriptions } \\
\text { while dashavidhapareeksha; Vaya; Hita, ahitaahara } \\
\text { and Satmya; Ashtouninditeeya, adhanyapraja }\end{array}$ \\
\hline $\begin{array}{l}\text { cognition, perception, emotions, attitudes, memory, psychological } \\
\text { needs psychological illness. }\end{array}$ & $\begin{array}{l}\text { Satwavaisheshikakara bhavaSatwabala } \\
\text { Satwaprakruti Factors for assessing the mind such as } \\
\text { cognition, intellect, consciousness, knowledge, } \\
\text { memory, desire, attitude, activities, behaviour, cus- } \\
\text { toms, and routines. Body-mind relationship }\end{array}$ \\
\hline $\begin{array}{l}\text { socio-economic status, education, impacts of technological devel- } \\
\text { opment/modernization/urbanization, social preferences towards } \\
\text { dresses and food, gender expectations, traditions, and customs. }\end{array}$ & $\begin{array}{l}\text { The influence of socio-economic factors in each ex- } \\
\text { amining factor of dashavidhapareeksha, } \\
\text { Attainment of cultured behaviour after studies, } \\
\text { Jatiprasakta, kula prasakta }\end{array}$ \\
\hline
\end{tabular}

\section{Guidelines for behavioural correction}

Know About/Make Knowledge/Get Aware - Due devotion to a noble person, Scriptural knowledge (enquire about to the experienced or learned, study about)

Think twice before the act, make a control over the actions, act good - Obeying/follow the wise/good, Avoid the company of bad people, Pursuit of the rules of good conduct, Compliance with scriptural prescriptions, Detachment from the objects of senses (take control over what we see and what we act), Absolute mental control, Abstinence from performing the bad acts,

Always keep in mind - Striving for do good acts and not to do bad acts, Annihilation of the effects of past actions/deeds, Concentration of the mind and intellect in the soul (analyze about oneself in every minute), Review of spiritual facts (continuous reading/remembrances and updating) 


\section{DISCUSSION}

Health behaviour is elaborated in Ayurveda classics as well as in other classical Indian literature. It is in the form of do's and don'ts while performing any kind of activity. Suppose you are teaching your children that the fire will burn you. Some will believe you, as you are reliable. But some can't understand unless they experience the same. Again, some will repeatedly do the same mistake without remembering the previous experience. Considering this simple instance, the behaviours can be extended to drug abuse, alcoholism, unsafe sex, violence and more. Despite communicating the good and bad effects, a section of people refrains from following the healthy way of life. This disrupts the health of society itself. It's because of the lack of a healthy mind processing before any action. That's why the actions done by the human body falls under the umbrella of psychology, as the psychotic process is responsible for one's favourable or unfavourable action. Misdeeds (actions in excess, inadequate or inappropriate) performed about body, mind and words are considered as one of the causes for diseases. The same is termed as prajnaparadha in Charaka Samhita. It is a violation of codes and conducts concerning our daily routines and social settings. Sins are nothing but these misdeeds. This explains how the ten major errors of actions of body, speech and mind are listed under ten sins by Vagbhata. The reasons for misdeeds are defects in psychotic processes before an act, like unawareness of subject/action, without a clear understanding of pros and cons and forgetting to act in time. To have positive health behaviour, one should have good awareness (education/knowledge), work out good actions (plan everything before doing) and abstain from bad acts. Undoubtedly, we can say that the prevention of misdeeds helps us to stay away from any kind of misery. The preventive aspects of the other two major reasons for illnesses -unsuitable sense perception (living in the healthier surrounding as well as refraining from the unhealthy sense objects) and environmental conditions come under the prevention of prajnaparadha itself. This includes proper awareness and preventive / management techniques of calamities (environmental hazards).

\section{CONCLUSION}

The idea of healthy behaviour is likely new to the modern world. But ancient Indian literature had explained the subject much before. The concept of health behaviour and health behaviour dynamics according to place and time are universal truths. But some of the examples are hard to accept in the present scenario, especially the social customs and traditions. It is because of the time itself. So pick the relevant, skip the unnecessary and update with newer ones.

\section{REFERENCES}

1. https://www.britannica.com/topic/human-behavior

2. https://www.ncbi.nlm.nih.gov/pmc/articles/PMC4511 $598 /$

3. https://www.studyandexam.com/behaviourdynamics.html

4. Yadavji Trikamji Acharya, Charaka Samhita Ayurveda Deepika commentary of Chakrapanidutta Reprint: 2009, Published by Chowkambha Krishnadas Academy, Varanasi; Uttarasthana, 4/8

5. Yadavji Trikamji Acharya, Charaka Samhita Ayurveda Deepika commentary of Chakrapanidutta Reprint: 2009, Published by Chowkambha Krishnadas Academy, Varanasi; sareerasthana, 6/12

6. Prof K.R. Srikantha Murthy. Vagbhata's Ashtanga Sangraham, English Translation:Chaukhambha Orientalia: Fourth edition:2003;Vol 2:shareerasthana; $1 / 62$

7. Yadavji Trikamji Acharya, Charaka Samhita Ayurveda Deepika commentary of Chakrapanidutta Reprint: 2009, Published by Chowkambha Krishnadas Academy, Varanasi; sareerasthana, 6/13

\section{Source of Support: Nil \\ Conflict of Interest: None Declared}

How to cite this URL: Dileep. G. L et al: A Review Of Health Behaviour Dynamics In Ayurveda. International Ayurvedic Medical Journal \{online\} 2021 \{cited August 2021\} Available from: http://www.iamj.in/posts/images/upload/1831_1838.pdf 